\title{
DESEGREGATION AND EQUITY IN HIGHER EDUCATION AND EMPLOYMENT: IS PROGRESS RELATED TO THE DESEGREGATION OF ELEMENTARY AND SECONDARY SCHOOLS?*
}

\author{
James M. McPartland ${ }^{\dagger}$
}

\section{INTRODUCTION}

Schools exist with an eye to the future. The main purpose of schools is to prepare the current generation of students to lead successful lives as adults and contribute to a worthwhile society. Thus any school policy or reform will be judged for its long-term consequences on the adult lives of its students and on the society they develop. Although the desegregation of America's public elementary and secondary schools is a policy established on the foundation of essential constitutional rights in this country, it will also be judged by its longterm effects, as any other educational change would be.

To argue that continued emphasis on school desegregation policies is necessary to achieve racial equity and desegregation in adult life, we need to know how far the nation still has to progress to achieve these goals. One may get a misleading impression of the current situation by relying only on gross tabulations of enrollments in higher education or rates of employment. To get a truer picture of the degree to which racial inequalities and segregation remain serious problems in higher education and employment, we need to consider the progress of the educational and occupational careers of minorities, compared with those of whites, after initial enrollment or employment; to examine the degree to which school and work environments are desegregated; and to determine whether there are differences between regions and between institutional levels. This article describes racial differences in higher education and employment, highlighting the lower educational persistence and completion rates of blacks compared to those of whites, the channeling of minorities

\footnotetext{
* This research was supported by a contract from the National Institute of Education for "Policy Studies in School Desegregation" (NIE-400-77-0054). The results and opinions do not necessarily reflect the position or policy of the National Institute of Education, and no official endorsement by the Institute should be inferred. The author thanks Denise Daiger and Lawrence F. Howe for their research assistance; Joyce L. Epstein, Linda S. Gottfredson, John H. Hollifield, Charles B. Thomas, and Gail E. Thomas for providing comments on earlier drafts; and Henry J. Becker for making data available.

$\dagger$ Co-director, Center for Social Organization of Schools, John Hopkins Universtiy.
} 
into a restricted range of major fields and careers that yield lower incomes, and the concentration of blacks in racially segregated college and work environments. This overview includes analyses of data obtained from recent government surveys that provide the first descriptions of desegregation in higher education and employment. ${ }^{1}$

After presenting a description of racial inequalities and segregation in higher education and employment, this article considers how the desegregation of elementary and secondary schools may affect these long-term outcomes. Direct evidence on how school desegregation may influence students' achievements and behavior in later life is difficult to find. Answering this question not only involves all the problems of analyzing the immediate effects of school desegregation with nonexperimental evidence ${ }^{2}$ but, by definition, requires an unusual amount of follow-up data to relate students' school experiences to their later lives. It should not be surprising, therefore, that in the otherwise extensive research literature on the effects of school desegregation, there are few direct studies of the long-term consequences of desegregation. This article reviews the currently available evidence and highlights some recent theories and predictions of how school desegregation is related to progress for racial equity and desegregation in higher education and employment.

\section{Higher Education}

Whether the progress that blacks have made since the 1960 s continues depends upon how they fare in higher education. Because of the trend toward universal high school graduation in this country, post-high school credentials are rapidly becoming the most important mark of educational distinction for entering the job market. Employers who wish to reduce the number of eligible candidates for a job often require educational credentials beyond the high school diploma. For minorities to be competitive, present trends to-

1. Data file tapes for the analyses undertaken for this article were obtained from the U.S. Department of Health, Education, and Welfare's 1972, 1974, and 1976 Surveys of Racial and Ethnic Enrollment in Institutions of Higher Education, and from the Equal Employment Opportunities Commission's 1975 Survey of Private Employers. Published versions of these studies are available in U.S. Dep't of Health, Educ., and Welfare, Office for Civil Rights, Racial and Ethic Enroliment Data from Institutions of Higher Education, Fall 1974 (1976); U.S. Dep't of Health, Educ., and Welfare, Office for Civit. Rights, Racial and Ethnic Enrollment Data From Institutions of Higher Education, Fall 1972 (Office for Civil Rights Report No. 74-13, 1974); M. Golladay, The Condition of Education: A Statistical Report on the Condition of Education in the United States (Nat'l Center for Educ. Statistics Report No. 76-400, March 1976); Equal. Employment Opportunities Comm'n, Job Patterns for Minorities and Women in Private Industry (Equal Employment Opportunities Comm'n Report No. 052-015-000-316, 1975).

2. See, e.g., Levin, Education, Life Chances, and the Courts: The Role of Social Science Evidence, 39 LaW \& Contemp. Prob., Spring 1975, at 217. 
ward equality in college enrollment and completion rates must continue. To be sure, black students still lag significantly behind whites in staying in and graduating from high school. About 25 percent of the black students drop out before completing high school, a percentage approximately twice that of white drop-outs. ${ }^{3}$ However, even possessing a high school diploma no longer gives one a very strong advantage in getting a job, because most of the current generation will receive this credential. Moreover, it appears to be even more important for blacks than for whites to have additional education beyond high school when seeking employment. Recent evidence suggests that the advantages whites have over blacks in terms of occupational opportunities are significantly greater for those with only a high school diploma than for collegetrained individuals. ${ }^{4}$ Therefore, if blacks are to continue socioeconomic progress, they must be successful in obtaining post-high school education.

Success in obtaining postsecondary education will also be more valuable to blacks than it was formerly because the efficacy of additional years of schooling for occupational success appears to be operating more equitably for blacks and whites in recent years, especially in the North. Research on social mobility in the 1960s indicated that education played a less significant role for blacks than for whites. The variables that had accounted for occupational success in white populations appeared to be less dependable for blacks in several ways: (1) the social mobility models explained variation in occupational careers less successfully for blacks than for whites, (2) amount of education failed to correlate as strongly with job success for blacks as for whites, and (3) advantages did not accumulate over generations in the same way for blacks as for whites (that is, blacks from middle-class homes more frequently lost increases in accumulated socioeconomic status than did whites with the same family advantages). Although discrimination and racially exclusionary processes probably continue to impede the progress of minorities in the $1970 \mathrm{~s},{ }^{5}$ differences in the role of

3. In 1973, the differences between black and white school enrollment were small before age 16 but large for the last two years of high school. Of 14- and 15-year-old black females, $96.9 \%$ were enrolled in school, compared to $97.2 \%$ of white females of the same age. The comparable figures for males were $96.9 \%$ of blacks and $98.1 \%$ of whites. But for that same year, $27.7 \%$ of black male and $23.0 \%$ of black female 18- and 19-year-olds were not enrolled in high school and were not high school graduates, while the comparable figures for male and female white students were $14.1 \%$ and $15.2 \%$. M. Golladay, The Condition of Education, 1977: A Statistical Report on the Condition of Education in the United States, vol. 3, pt. 1, 197 (Nat'l Center for Educ. Statistics Report, 1977); U.S. Bureau of the Census, Current Population Reports, Ser. P. 20, No. 272, Population Characteristics 55-56 (1974).

4. See, e.g., C. Jencks, Effects of Family Background, Test Scores, Personality Traits and Schooling on Economic Success, ch. 8 (Final Report to U.S. Dep't of Labor, Manpower Administration, April, 1977). A revision of this report, C. JENCks, Who Gets Ahead?, will be published in 1979.

5. See, e.g., McPartland \& Crain, Racial Discrimination, Segregation, and Processes of Social Mability, in Committee on Evaluation of Poverty Research, Perspectives on Poverty (forthcoming National Research Council report, 1979). 
education in the social mobility processes of blacks and whites appear to be much less striking in recent years. ${ }^{6}$ Blacks and other minorities need to invest in postsecondary schooling if they are to take advantage of the recently more available avenues of social mobility through education.

Accepting post-high school education as critical for continued minority progress, one must examine the current differences between blacks and whites in attainments in higher education, the present state of desegregation in higher education, and the relationship of elementary and secondary school desegregation to these two issues.

\section{A. Attainments in Higher Education}

National data on differences between the postsecondary education attainments of blacks and whites have until recently been available only for a limited number of criteria. For example, data were available on the differential rates of initial enrollment in the first year of college, but it was difficult to measure black-white differences in continuation or completion rates, in the type and quality of provided programs, in the pattern of part-time versus full-time enrollment or in continuous versus interrupted schooling, and in access to institutions within close commuting distance or to financial assistance.

A hopeful sign of movement toward more equal achievement in higher education is found in a number of recent studies indicating that blacks approach postsecondary schooling with strong ambition. Black high school graduates' aspirations for higher education and their initial enrollment rates in postsecondary schools are much higher than those of whites of similar social class or test score levels and nearly the same as that of whites, regardless of background. ${ }^{7}$ However, there is some indication that the gaps between

6. The social mobility model that has been the major influence in this work was developed in P. Blau \& O. Duncan, The American Occupational Structure (1967). Recent research that has studied changes in black and white social mobility processes includes Hauser \& Featherman, Equality of Schooling: Trends and Prospects, 49 Soc. Educ. 99 (1976); R. Hauser \& D. Featherman, The Process of Stratification: Trends and Analyses (1977); Featherman \& Hauser, Changes in the Socioeconomic Stratification of the Races 1962-73, 82 AM. J. Soc. 621 (1976); Hogan \& Featherman, Racial Stratification and Socioeconomic Change in the American North and South, 83 AM. J. Soc. 100 (1977).

7. The Bureau of the Census recently reported that blacks comprised $10.7 \%$ of all college students 16 to 34 years old in 1976 and $11.7 \%$ of the civilian population of the same ages. U.S. Bureau of the Census, Current Population Reports, Ser. P-20, No. 309, Population Characteristics 2 (1977). Several studies have shown the greater college enrollment rates of black high school graduates compared to whites of similar social class and similar test score levels, including recent analyses of the Youth in Transition study (J. G. Bachman, R. L. Kahn, M. T. Mednick, T. N. Davidson, \& L. D. Johnson, Youth in Transition: Blueprint for a Longitudinal Study of Adolescent Boys (University of Michigan Institute for Social Research report, 1967), reported in Portes \& Wilson, Black-White Differences in Educational Attainment, 41 AM. Soc. REv. 414 (1976)), and of the National Longitudinal Study of the High School Class of 1972, reported in W. Fetters, National. Longitudinal. Study of the High School. Class of 1972: Comparative 
black and white enrollment rates increase over the college years, though the data are not yet available for direct investigation of comparative continuation and completion rates in college for representative samples of blacks and whites ${ }^{8}$ For example, the 1976 report of the National Center for Education Statistics estimates that 40.9 percent of the black freshman class of 1971 were enrolled as seniors in 1974 , compared to 57.2 percent of the white freshman class. ${ }^{9}$ Data from the National Longitudinal Study of the High School Class of 1972 show that after two years, 47.7 percent of black two-year college entrants had withdrawn from higher education, compared to 38.3 percent of whites, and that 27.3 percent of blacks enrolled in four-year institutions had withdrawn, compared to 23.3 percent of whites. ${ }^{10}$ In addition, there are indications that blacks experience proportionately more part-time or interrupted schooling in attaining their college credentials than do whites. On the average, blacks who complete postsecondary training take more years to do so and are older when they receive their degrees than whites are. ${ }^{11}$ One study of the alternate routes taken to achieve an educational diploma or degree shows that "[f]ewer blacks than whites resume their education once it is interrupted and of those who do resume, fewer blacks than whites convert this resumption into degree attainment." 12 This study also shows that blacks and whites differ

Profiles One and One-Half Years After Graduation (1975); M. Golladay, supra note 3, at 200. See also Thomas, Alexander, \& Eckland, Access to Higher Education: How Important Are Race, Sex, Social Class and Academic Credentials for College Access? (Johns Hopkins University Center for Social Organization of Schools, Report 226, 1977); Peng, Bailey, \& Ekland, Access to Higher Education: Results from the National Longitudinal Study of the High School Class of 1972, 6 EDuC. RESEARCHER, December 1977 , at 3-4.

8. A major recent work to estimate college access, distribution, and persistence rates of blacks and whites is Institute for the Study of Educational Policy at Howard University, Equal Educational Opportuntty for Blacks in U.S. Higher Education: An Assessment (1976). Making such estimates had been hampered by the absence of basic national data on the racial distribution of undergraduate conferred degrees and by the absence of longitudinal data on race of college students through the completion of the senior year. For future research, these deficiencies have been mitigated by the sample survey on college degrees conducted by the American Council on Education, see F. J. Atelsek and I. L. Gomberg, Bachelors Degrees Awarded to Minority Students 1973-74 (American Council on Education, Higher Education Panel Reports No. 24, 1977), and by the follow-up surveys of the National Longitudinal Study of the High School Class of 1972 conducted by the U.S. Dep't of Health, Educ., and Welfare, National Center for Education Statistics.

9. See M. Golladay, supra note 3, at 94 .

10. See A. Kolstad, Attrition from College: The Class of 1972 Two and One-Half Years After High School Graduation, at 6 (National Longitudinal Study of the High School Class of 1972, U.S. Dep't of Health, Educ., and Welfare, Nat'l Center for Educ. Statistics, Report $77-266,1977)$.

11. Institute for the Study of Educational Policy at Howard University, supra note 8, at 19 .

12. N. L. Karweit, Patterns of Educational Activities: Discontinuities and Sequences 10, 20 (Johns Hopkins University Center for Social Organization of Schools Report No. 222, January 1977). 
in their combinations of full-time and part-time schooling to reach an educational destination, with blacks less likely to engage in part-time upgrading of their education. ${ }^{13}$

There are also indications of major differences in the type and quality of the higher education institutions attended by minority and white students. Tabulations of the 1976 Department of Health, Education, and Welfare survey of racial and ethnic enrollments in higher education show that 44.8 percent of black first-year, full-time undergraduates enroll in two-year institutions rather than four-year institutions, compared to 37.1 percent of whites. ${ }^{\mathbf{1 4}}$ Analyses of the American Council on Education's survey of students entering college as first-time, full-time freshmen indicate that minority students are overrepresented in the two-year and nonselective four-year colleges and underrepresented in the universities. These studies show that the net cost (tuition minus aid) to many students is often not very different in schools of high and low selectivity. (Although tuition is lower in the less selective schools, so is the amount of financial aid available. $)^{15}$ Finally, blacks and whites enroll in different proportions in various majors and fields of study. Blacks are more likely to major in education and social service fields; this tendency increases between the baccalaureate and doctoral levels. ${ }^{16}$ The continued concentration of minorities in particular fields has implications for occupational and income mobility. Research showing that the occupational payoff from additional years of schooling is lower for certain types of work, with social service occupations having particularly low income returns from increased schooling, is discussed in Part II of this article.

Thus, relying solely on statistics of initial enrollment rates does not provide an accurate picture of the recent progress of blacks in higher education. While proportionately as many blacks as whites may begin postsecondary schooling, this review of research indicates that they are much more likely to enter lower quality institutions. (such as two-year colleges), to fail to complete college and receive a degree, and to be concentrated in a restricted range of major fields.

\section{B. Desegregation in Higher Education}

The structure of higher education in this country differs in many ways from the structure of elementary and secondary education, making it difficult to apply the policies and perspectives formulated in connection with elemen-

\footnotetext{
13. Id. at 13-14.

14. Unpublished tabulations performed at Johns Hopkins University.

15. See Astin, Equal Access to Postsecondary Education: Myth or Reality? 19 UCLA Educator, Spring 1977, at 8, 11-12.

16. Institute for the Study of Educational Policy at Howard University, supra note 8, at 61 .
} 
tary and secondary school desegregation to colleges and universities. ${ }^{17}$ In contrast to the lower levels of schooling, higher education reflects a wider diversity of approaches in its mixture of public and private institutions, its variety of state approaches with different types of schools and admissions policies, its collection of commuter and residential schools that may draw from local or national student populations, and its traditionally black institutions that have a proud history of educating a large proportion of black professionals and leaders. In order to assess the current conditions and trends in desegregation of higher education, better information on the enrollment patterns in all of these institutions is needed.

The federal government has surveyed the racial and ethnic enrollments of all institutions of higher education every two years since 1968, but these data have not previously been used to determine the extent to which American colleges and universities remain segregated. The data collected in 1972, 1974, and 1976 are analyzed in this article to ascertain the trends in the segregation of higher education during these years. A segregation index is calculated for enrollments in different regions and types of institutions. The segregation indices computed for 1976 are given in Table 1.

The segregation index measures the degree of racial separation among institutional enrollments, standardized for the availability of minority and white students in a given region and postsecondary level. The segregation index consists of two components. The first component is the actual amount of racial separation experienced by the minority students, or the "percent white in the school attended by the average minority student." 18 The second component is the expected racial separation to be experienced by minority students if the available minority and white students were randomly distributed among the schools, or the percentage of all students who are white. ${ }^{19}$ These two components are used in the segregation index to measure the extent to which the actual percentage of white students in the school attended

17. See National Public Radio, Transcript of October 7, 1974 broadcast of "Options in Education" for a sampling of opinions of desegregation of higher education and the role of black colleges.

18. The first component of the segregation index is a weighted average of school racial proportions. For this component, the "percent white in the school attended by the average minority student" is calculated by the average across schools of the percent white enrollment, weighted by the number of minorities in the school. (In these calculations, the category of minority students includes all Black, American Indian or Alaskan Native, Asian or Pacific Islander. Hispanic, and Nonresident Alien students.) In Table 1, col. 1, for example, the average minority undergraduate student in the nation attends a school that is $57.6 \%$ white. In other words, of every 100 students encountered by the average minority undergraduate student, about 57 of them will be white.

19. The second component of the segregation index-the expected racial composition of the average school if the available minority and white students were randomly distributed among the schools-is simply the percentage of all students who are white. As shown in Table 1, col. 2.84\% of the undergraduate students in the nation are white. Thus, if all students were randomly distributed among the undergraduate schools in the country. the average minority student would attend a school where the racial composition was $84 \%$ white. 
TABLe 1

1976 Segregation Indices for Full-Time ENRollment in Highfr Education, by Level and Region

$\begin{array}{cccccc}\text { Percent White } & \begin{array}{c}\text { Percent } \\ \text { in the School } \\ \text { Attended by } \\ \text { the Average } \\ \text { Minority } \\ \text { Student }\end{array} & \begin{array}{c}\text { Percent White } \\ \text { Students } \\ \text { in the } \\ \text { Region }\end{array} & \begin{array}{c}\text { Minority } \\ \text { in the School } \\ \text { Attended by } \\ \text { the Average } \\ \text { White Student }\end{array} & \begin{array}{c}\text { Percent } \\ \text { Minority } \\ \text { Students } \\ \text { in the } \\ \text { Region }\end{array} & \begin{array}{c}\text { Segre- } \\ \text { gation } \\ \text { Index }\end{array} \\ \begin{array}{c}\text { Region1 } \\ \text { All Undergraduates }\end{array} & 57.6 & 84.0 & 10.9 & 15.9 & 31.4 \\ \text { Nation } & 66.1 & 87.9 & 9.1 & 12.0 & 25.0 \\ \text { NE } & 68.2 & 89.8 & 7.7 & 10.1 & 23.7 \\ \text { MW } & 45.4 & 78.5 & 12.4 & 21.4 & 42.5 \\ \text { S } & 64.2 & 80.2 & 15.8 & 19.7 & 20.3 \\ \text { W } & & & & & \end{array}$

Undergraduates in Two-

Year Institutions

Nation
NE
MW
S
W

$\begin{array}{lrrrr}54.6 & 77.9 & 15.4 & 22.0 & 30.0 \\ 49.2 & 82.7 & 10.3 & 17.2 & 40.1 \\ 47.1 & 83.9 & 9.0 & 16.0 & 43.7 \\ 56.9 & 73.5 & 20.5 & 26.4 & 22.7 \\ 58.0 & 74.6 & 19.7 & 25.3 & 22.1\end{array}$

Undergraduates in Four-

Year Institutions

$\begin{array}{lrrrrr}\text { Nation } & 59.4 & 86.2 & 9.4 & 13.7 & 31.3 \\ \text { NE } & 74.4 & 89.5 & 8.7 & 10.4 & 16.3 \\ \text { MW } & 79.2 & 91.4 & 7.4 & 8.5 & 12.9 \\ \text { S } & 40.2 & 80.3 & 9.8 & 19.6 & 50.0 \\ \text { W } & 70.3 & 83.8 & 13.5 & 16.1 & 16.1\end{array}$

Graduate-Professional

Nation

NE

$80.2 \quad 90.8$

$90.8 \quad 8.0$

$8.0 \quad 9.1 \quad 12.0$

MW 86 .

$92.4 \quad 7.3$

92.6

89.6

6.8

12.0
4.0

$\mathrm{S}$

68.6

W

82.3

88.1

8.0

$\begin{array}{rr}7.3 & 8.2 \\ 10.3 & 23.3\end{array}$

$\begin{array}{rr}7.3 & 8.2 \\ 10.3 & 23.3\end{array}$

${ }^{1}$ Northeast $(\mathrm{NE})=\mathrm{CT}, \mathrm{DE}, \mathrm{ME}, \mathrm{MA}, \mathrm{NH}, \mathrm{NJ}, \mathrm{NY}, \mathrm{PA}, \mathrm{RI}, \mathrm{VT}$.

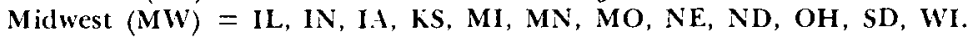

South (S) $=\mathrm{AL}, \mathrm{AR}, \mathrm{DC}, \mathrm{FL}, \mathrm{GA}, \mathrm{KY}, \mathrm{LA}, \mathrm{MD}, \mathrm{MS}, \mathrm{NC}, \mathrm{OK}, \mathrm{SC}, \mathrm{TN}, \mathrm{TX}, \mathrm{VA}$, WV. West (W) = AK, AZ, CA, CO, HI, ID, MT, NV, NM, OR, UT, WA, WY.

Source: Data file tapes from the 1976 National Center for Education Statistics Survey of Racial and Ethnic Enrollments in Institutions of Higher Education.

by the average minority student departs from the percentage expected if students were randomly distributed. ${ }^{20}$

20. The formula is as follows:

\begin{tabular}{|c|c|c|c|c|c|}
\hline Segregation & $\begin{array}{l}\text { Percent } \\
\text { white } \\
\text { students in } \\
\text { the region }\end{array}$ & $\begin{array}{l}\text { Percent white } \\
\text { in the school } \\
\text { attended by the } \\
\text { - average minor- } \\
\text { ity student in } \\
\text { the region }\end{array}$ & $\begin{array}{l}\text { Percent } \\
\text { minority } \\
\text { students in } \\
\text { the region }\end{array}$ & \multicolumn{2}{|c|}{$\begin{array}{l}\text { Percent minority } \\
\text { in the school } \\
\text { attended by the } \\
\text { - average white } \\
\text { student in } \\
\text { the region }\end{array}$} \\
\hline Index & $\begin{array}{l}\text { Perc } \\
\text { stud } \\
\text { the }\end{array}$ & $\begin{array}{l}\text { at white } \\
\text { ts in } \\
\text { gion }\end{array}$ & $\begin{array}{l}\text { Perce } \\
\text { stude } \\
\text { the re }\end{array}$ & & \\
\hline
\end{tabular}


The index will have a value of 100 whenever white and minority students attend entirely separate schools; it will have a value of 0 whenever the actual racial composition of the schools is the same as a random allocation of the students would produce. Index values between 0 and 100 measure the degree of segregation for the particular region and type of school under consideration. The larger the value of the index, the more segregated or "racially isolated" is the school population of white and minority students. Segregation indices can be used to compare the degree of segregation either between different groups of schools or in the same schools at different points in time.

The segregation indices given in Table 1 indicate that when all undergraduates, regardless of the type of school attended, are considered, the most segregated region is the South, which has a segregation index of 42.5, compared to values ranging from 25.0 to 20.3 for other regions. But when twoyear institutions are examined, the Northeast (40.1) and Midwest (43.7) regions have the most segregated full-time students.

The range of experiences that are summarized in the segregation indices is given in Table 2. For example, 16.8 percent of all minority undergraduate students attend schools with a white enrollment of less than 10 percent, 26.2 percent of all minorities attend schools where less than one-quarter of the students are white, and 35.4 percent attend schools where less than half of the enrollment is white. The distribution of white undergraduate students by school racial composition is also shown in Table 2. Only 1.5 percent of white undergraduates attend schools where minority students comprise more than half of the enrollment, while 90.9 percent are in schools where minority students comprise less than one-quarter of the school's student population.

The pattern of regional differences at different levels of higher education is most striking when the minority student experience is considered. Among two-year institutions, minority students are most racially isolated in the Midwest, where 23.9 percent attend schools where whites are less than 10 percent

For a further description of this index, see J. Coleman, S. Kelly, \& J. Moore, Trends in School SEgRegation, 1968-73, at 7 (1975). This index avoids some of the bias problems that are inherent in other indices of segregation used in the desegregation literature. See, e.g., Cortese, Falk, \& Cohen, Further Considerations on the Methodological Analysis of Segregation Indices, 41 AmER. Soc. Rev. 630 (1976).

Each value of the segregation index presented in Table 1 is an average of the index calculated from the perspective of the average white student and of the average black student, using components that include more decimal places than are shown in columns $1-4$. These reported values may differ somewhat from values calculated from the single decimal place components shown in the table.

The segregation index can also be based on components derived from the perspective of the average white student. The average white undergraduate student in the nation, as shown in Table 1, col. 3, attends a school with a $10.9 \%$ minority enrollment. Minority students, as shown in Table 1, col. 4, comprise $15.9 \%$ of the nation's undergraduate population, the expected percentage of minority enrollment in the average school attended by the average white student if all students were randomly distributed among the schools. 


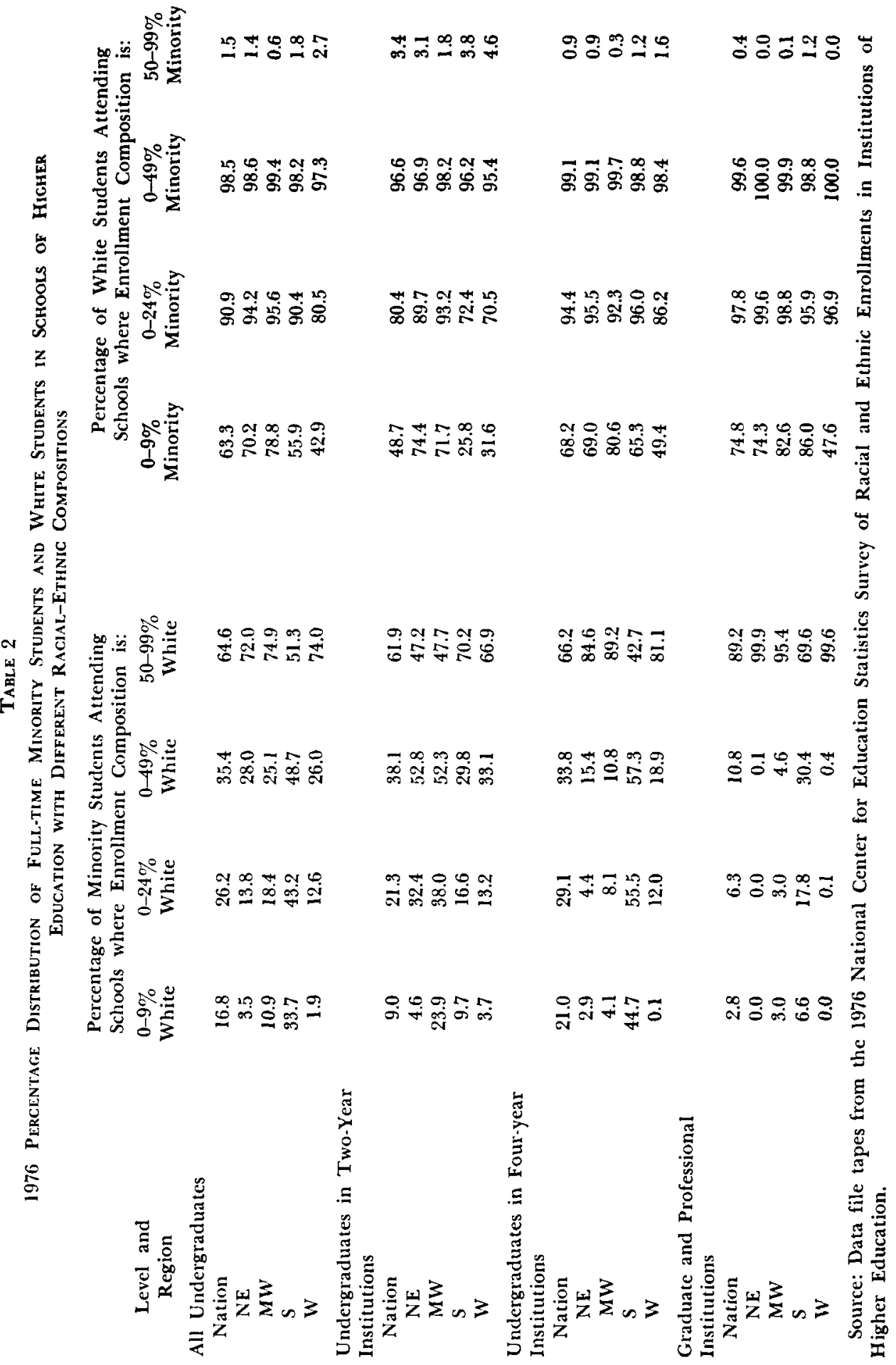


of the enrollment. Among four-year undergraduate institutions, minority students are most racially isolated in the South, where 44.7 percent attend schools with less than 10 percent white enrollment. Among graduate-professional institutions, minority students in every region are much less racially isolated than at the undergraduate levels. The percent of minority graduate-professional students attending schools in the most racially isolated category (0-9 percent white) ranges from 0 in the Northeast and West to 6.6 in the South. However, although segregation is least prevalent at the graduate-professional level, the proportion of minority students who have gained access to any institution at this level is also much less than at undergraduate levels. ${ }^{21}$ In other words, the fact that minority students are significantly underrepresented as graduate or professional students is much more serious than the degree to which en rollments are segregated at this level.

As noted earlier, segregation indices are useful not only for comparing the degree of segregation between schools in different regions or different types of schools, but also for comparing the change in the degree of segregation over time. Segregation indices for the years 1972, 1974, and 1976, distinguishing between public and private institutions, between regions, and between institutional levels, are presented in Table 3. Although the South remains the most highly segregated region for four-year undergraduates and for graduate and professional students, it is the only region in which segregation has diminished since 1972. Among the public four-year institutions in the South, the segregation indices decreased from 56.6 to 45.6 between 1972 and 1976 . Among the public graduate-professional institutions, the indices decreased from 26.5 to 19.1 in this region.

Although postsecondary segregation is high in four-year Southern institutions (50.0) and in two-year Northeastern (40.1) and Midwestern (43.7) institutions, there is less segregation nationwide at the higher education level than among public elementary and secondary schools. The segregation index for 1972 for all undergraduates in the nation's colleges and universities is $31.7,{ }^{22}$ compared to 55.8 for elementary and secondary schools. ${ }^{23}$ In terms of the distribution of minority students, 32.5 percent of minority undergraduates

21. See Table 1, col. 4. The underrepresentation of minority students at the graduateprofessional level is shown in Table 1 by comparing the values of the "Percent Minority Students in the Region" for undergraduates and graduate-professionals. In the Northeast, $12.0 \%$ of undergraduates are minorities compared to $7.5 \%$ of graduate-professionals who are minorities. The analogous comparison is $10.1 \%$ versus $7.3 \%$ in the Midwest, $21.4 \%$ versus $10.3 \%$ in the South, and $19.7 \%$ versus $11.8 \%$ in the West.

22. See Table 3, col. 7 .

23. This figure is based on a re-analysis of the regional segregation indices for elementary and secondary schools reported in J. Coleman. S. Kelly. \& J. Moore, supra note 20, at 28, and of the distributional statistics reported in M. Golladar, supra note 3, at 67 . 
TABle 3

Comparison of 1972, 1974 ANd 1976 SEgregation Indices for FUll-time ENRollment in Higher Education, by Level, Region and Control

\begin{tabular}{c}
$\begin{array}{c}\text { Level and } \\
\text { Region }\end{array}$ \\
\hline \\
All Undergraduates \\
Nation \\
NE \\
MW \\
S \\
W
\end{tabular}

\begin{tabular}{ccr}
\multicolumn{3}{c}{ Public } \\
\hline 1972 & 1974 & 1976 \\
& & \\
30.4 & 29.5 & 30.5 \\
20.3 & 18.1 & 31.4 \\
24.6 & 22.6 & 24.7 \\
47.5 & 42.5 & 37.3 \\
11.8 & 17.2 & 9.1
\end{tabular}

\begin{tabular}{rrr}
\multicolumn{3}{c}{ Private } \\
\hline 1972 & 1974 & 1976 \\
& & \\
35.5 & 34.0 & 34.5 \\
4.6 & 23.5 & 9.1 \\
14.4 & 20.2 & 23.0 \\
66.8 & 60.9 & 60.3 \\
10.8 & 13.1 & 12.3
\end{tabular}

\begin{tabular}{ccc}
\multicolumn{3}{c}{ All } \\
\hline 1972 & 1974 & 1976 \\
& & \\
31.7 & 31.1 & 31.4 \\
16.3 & 21.9 & 25.0 \\
22.7 & 22.0 & 23.7 \\
51.4 & 47.0 & 42.5 \\
12.2 & 16.5 & 20.3
\end{tabular}

Undergraduates in Twoyear Institutions

Nation
NE
MW
S
W

$\begin{array}{lllllllll}25.7 & 25.4 & 29.4 & 38.0 & 41.0 & 42.1 & 26.6 & 27.5 & 30.0 \\ 29.7 & 26.7 & 42.2 & 14.4 & 35.1 & 27.1 & 29.1 & 35.2 & 40.1 \\ 45.5 & 40.9 & 43.8 & 15.4 & 21.6 & 46.5 & 43.6 & 39.8 & 43.7 \\ 20.9 & 19.2 & 20.9 & 53.6 & 60.0 & 49.6 & 24.4 & 22.2 & 22.7 \\ 15.7 & 21.5 & 21.9 & 67.2 & 48.1 & 54.1 & 16.1 & 22.0 & 22.1\end{array}$

Undergraduates in Four. year Institutions

$\begin{array}{lrrrrrrrrr}\text { Nation } & 32.4 & 32.1 & 30.4 & 35.2 & 32.5 & 33.8 & 33.0 & 31.9 & 31.3 \\ \text { NE } & 14.0 & 12.1 & 23.0 & 4.7 & 15.3 & 7.3 & 9.8 & 14.4 & 16.3 \\ \text { MW } & 10.0 & 12.5 & 11.1 & 13.7 & 19.7 & 18.7 & 10.7 & 14.2 & 12.9 \\ \text { S } & 56.6 & 52.3 & 45.6 & 68.4 & 61.1 & 61.4 & 59.7 & 54.6 & 50.0 \\ \text { W } & 8.0 & 9.3 & 16.8 & 7.4 & 10.1 & 10.7 & 7.4 & 9.5 & 16.1 \\ \text { Graduate-Professional } & & & & & & & & & \\ \text { Nation } & 11.6 & 9.5 & 10.1 & 16.8 & 18.0 & 13.8 & 13.7 & 13.6 & 12.0 \\ \text { NE } & 5.3 & 3.7 & 3.7 & 2.8 & 5.2 & 2.7 & 3.8 & 3.8 & 4.0 \\ \text { MW } & 1.6 & 4.3 & 2.9 & 4.3 & 8.0 & 13.4 & 3.2 & 4.2 & 8.2 \\ \text { S } & 26.5 & 21.7 & 19.1 & 42.7 & 46.2 & 29.1 & 31.7 & 30.8 & 23.3 \\ \text { W } & 2.7 & 4.0 & 7.2 & 6.1 & 5.5 & 3.8 & 3.6 & 3.9 & 6.7\end{array}$

Source: Data file tapes from 1972 and 1974 Department of Health, Education and Welfare Office of Civil Rights and 1976 National Center for Education Statistics Surveys of Racial and Ethnic Enrollments in Institutions of Higher Education.

in 1972 attended schools where less than half of the enrollment was white, ${ }^{24}$ compared to 60.4 percent at the elementary-secondary level. ${ }^{25}$ The differences are smallest in the South, where 56.6 percent of minorities in higher education $^{26}$ compared to 57.7 percent of minorities at the elementary-secondary level attended schools where less than half of the students were white. ${ }^{27}$ In the other regions of the country, there is a much greater contrast in the degree of segregation between higher education (only 15.4 percent of

24. Unpublished tabulations of the 1972 Survey of Racial and Ethnic Enrollments in Institutions of Higher Education, supra note 1, performed at Johns Hopkins University.

25. Supra note 23.

26. Id.

27. Id. 
all undergraduate minorities attended predominantly minority schools in $1972)^{28}$ and elementary and secondary education (62.6 percent of all minority students attended predominantly minority schools). ${ }^{29}$

Further analyses need to be undertaken in order to make the higher education enrollment data more useful to researchers, educators, and policymakers. It will be especially important to examine trends in both desegregation and minority representation at each level of higher education, because advances toward one goal may be at the expense of the other. Research that simultaneously measures progress in desegregation and progress in the overall minority representation in postsecondary education is needed to make sure that improvements in desegregation do not result in fewer minority students' gaining access to college-and that gains in minority postsecondary enrollments are not concentrated in segregated institutions. This research must also examine the role of historically black institutions and the state-by-state variations in the location of schools and populations of white and minority students. ${ }^{30}$

This review of the descriptive evidence on black-white differences in higher educational attainment and on desegregation in higher education suggests some research questions about the effects of desegregation in elementary and secondary schools: Does desegregation in the earlier grades tend to foster minority student college entrance and graduation, especially at four-year institutions? Are minority students who have attended desegregated elementary and secondary schools more likely to enroll in desegregated postsecondary institutions? Are they more likely to continue and complete their education in desegregated colleges or universities if they have previously attended desegregated schools? Are the college enrollment choices of white students affected by their experiences in segregated or desegregated elementary and secondary schools? Although no evidence is presently available on the perpetuation of segregation across educational levels, there are some studies of effects of desegregation on other postsecondary outcomes. These are reviewed in the next section of this article.

\section{Elementary and Secondary School Desegregation and Outcomes in Higher Education}

A limited number of studies have examined whether attending a desegregated elementary or secondary school is related to the attainment of higher education by black students and to the types of colleges and programs in which they en roll. These studies include a retrospective survey of black adults, some small follow-up studies of unusual secondary school desegregation ex-

\footnotetext{
28. Id.

29. Id.

30. These analyses are in progress under the direction of Gail E. Thomas at Johns Hopkins University.
} 
periments, and some recent longitudinal surveys of national samples of young adults of both races.

In 1966, the United States Commission on Civil Rights sponsored an interview survey of 1,624 black adults, in which the respondents reported whether they had attended segregated or desegregated elementary and secondary schools (about 650 of the total interviewed had attended desegregated schools), and described their postsecondary educational attainment. ${ }^{31} \mathrm{Al}$ though the period of the elementary and secondary school experiences reported in this study extended from the 1930s to the early 1960s-the adult population surveyed in 1966 ranged from ages seventeen to forty-five and lived in the metropolitan areas of North and West-these data present a unique insight into desegregated schooling and its effects on the later lives of a minority population.

One study analyzing these data found that blacks who attended desegregated schools are more likely to have completed both elementary and high school and to attend and complete college than those who attended segregated elementary and secondary schools. ${ }^{32}$ Thirty-two percent of Northernborn males who attended desegregated schools went to college compared to twenty-four percent of Northern-born males who attended segregated schools. The differences for women were small but weighted in the same direction. While the sample of those minorities who graduated from college was very small, the data similarly indicated that blacks who had attended desegregated schools were more likely to graduate. These findings were independent of whether or not they had been born in the North or the South, regardless of the age at which the respondent moved North, and regardless of parental background factors. ${ }^{33}$

Two studies based on small samples of black students who participated in unusual desegregation programs related college attendance to having attended desegregated schools before high school graduation. In an otherwise negative assessment of the effects of desegregation experiments, David Armor's review of two situations where effects on college attendance were measured found some positive outcomes. ${ }^{34}$ Both situations involved small numbers of students and unusual desegregation programs. The METCO program was a voluntary program in metropolitan Boston in which black students were bused across district lines. College data were obtained for thirty-two bused and sixteen control group students (who were siblings of the students desegregated by busing) for 1972. These students represented about two-thirds of the original experimental and control groups of high school seniors in

31. U.S. Comm'n on Civil Rights, 1 Racial Isolation in the Public Schools (1967).

32. Crain, School Integration and Occupational Achievement of Negroes, 75 AMER. J. Soc. 593 (1970).

33. Id, at 602 , Table 9 .

34. Armor, The Evidence on Busing, 28 Pub. Interest, Summer 1972, at 90, 105-06. 
1970. The study indicated that although the METCO-bused students were much more likely to start college than the control group, these same students had a much higher drop-out rate from college ${ }^{35} \mathrm{By}$ the end of the sophomore year, there were no large differences in college attendance favoring the METCO-bused students, although the METCO students who remained in college were enrolled in higher-quality institutions (predominantly four-year colleges and universities) compared to the control group. ${ }^{36}$ In a critical review of this study, ${ }^{37}$ it was argued that the positive evidence for the METCO program is stronger than the study suggests: the dropout rate of the black METCO students from four-year colleges and universities was slightly less than that for white students nationally. The retention rates for black METCO students enrolled in such institutions was considerably higher than that of other black students: 56 percent compared to 38 percent remained in four-year colleges, and 43 percent compared to 12 percent remained in universities. ${ }^{38}$

The second study reviewed by Armor that indicates that there are some positive effects of desegregated schooling on postsecondary school education is the ABC ("A Better Chance") program. ${ }^{39}$ This 1971 follow-up study of the first year of college involved about forty high-ability black students who had participated in the highly selective $\mathrm{ABC}$ program of scholarships awarded to enable them to attend predominantly white high prestige private secondary schools and residential public secondary schools. These forty students were matched with a control group of black students of similar background and achievement levels who had applied to the $\mathrm{ABC}$ program but who could not be placed due to a cutback in federal funding. All the $\mathrm{ABC}$ students entered colleges, compared to about half the control group, and the $\mathrm{ABC}$ students enrolled in considerably higher quality colleges than did the control group. ${ }^{40}$ Follow-up data on differential dropout rates were not available for study. ${ }^{41}$

Three longitudinal surveys of students after their graduation from high school have been analyzed to determine the effect of desegregation on the college success of black students. Two of these analyses, one using data from the Project TALENT survey ${ }^{42}$ and the other using data from the Youth in

35. Armor, supra note 34 , at 105.

36. Id. at 105-06

37. Pettigrew, Useem, Normand, \& Smith, Busing: A Review of "The Evidence," 30 PuB. INTEREST 88, $110-11$ (1973).

38. Id. at 111 .

39. Armor, supra note 34 , at 106 .

40. Id.

41. Id.

42. D. Kapel, Effects of Negro Density on Student Variables and the Post-High School Adjustment of Male Negroes (American Institute for Research, Project TALENT Five-Year Follow-Up Studies Interim Report No. 6. 1968) (ERIC Document No. 029 074); and D. Kapel, Environmental Factors, Student Variables, Post-High School Employment Adjustment, and Post-High School Education of Male Negroes from the Project TALENT Sample (Dep't of Health, Educ., and Welfare, Office of Educ., 1969) (ERIC Document No. 027 888). 
Transition survey, ${ }^{43}$ involved very small and unrepresentative samples of black students, so that the results are of limited value. However, a continuing longitudinal survey of the High School Graduating Class of 1972 includes a large representative sample of black students and is an important source of useful research data.

The Project TALENT study, which may be quite biased, ${ }^{44}$ found neither positive nor negative effects of school desegregation on post-high school education. ${ }^{45}$ The Youth in Transition study, which may also be biased ${ }^{46}$ because of its very small sample of black students, indicates that the social mobility process of desegregated blacks more closely approximates that for whites. ${ }^{47}$ This is in contrast to the more typical finding of large differences between blacks and whites in the importance of academic performance and socioeconomic background to advanced educational attainments.

The National Longitudinal Study (NLS) of the High School Graduating Class of 1972 provides data on a large sample of high school students surveyed as seniors in 1972 and later in 1973, 1974, and 1976. ${ }^{48}$ The sample included nearly 3,000 black respondents, of whom about 1,000 attended Northern high schools and 2,000 attended Southern high schools. In each region, there appears to be a sufficient sample of students from both segregated and desegregated elementary or secondary schools to examine questions about effects on college attendance. In addition, the follow-up response rates have been unusually good, exceeding 90 percent for each of the three follow-up surveys. On the other hand, there is no way in this study to control for differential high school dropout rates, because only high school seniors were initially sampled; and critical data on achievement test performance in high school is missing for about 30 percent of the sample.

Two studies of the effects of elementary and secondary school desegregation on black students' college attendance, using the NLS data, have been

43. Portes \& Wilson, supra note 7.

44. In the initial 1960 Project TALENT survey, respondents were not asked their race. The 1965 survey, which did ask for the racial identity of the respondent, was a follow-up of the original 1960 student sample. The overall response rate was very low-39\%-and there is no way to know either the response rate for blacks or the extent of the bias. From an original sample of over 90,000, only 224 blacks were included in the desegregation study, only 74 of whom had attended desegregated schools.

45. D. Kapel, Environmental Factors, Student Variables, Post-High School Employment Adjustment, and Post-High School Education of Male Negroes from the Project Talent Sample, supra note 42 , at 11,16 .

46. In the Youth in Transition study, comparisons were made one year after high school between subsamples of 73 black students who attended desegregated schools, 72 who attended segregated Northern schools. and 111 from segregated Southern schools. The follow-up rate was $80 \%$ of a nationally representative sample of 2,213 black and white high school students.

47. Portes \& Wilson, supra note 7 , at 429.

48. J. Levinsohn, L. Henderson, J. Riccobono, \& R. Moore, National longitudinal Survey. Data File Users' Manual (Nat'l Center for Educ. Statistics Report, April 1978). 
reported. ${ }^{49}$ The two studies make different assumptions about the variables to be statistically controlled before examining the influence of school desegregation, use different measures of college enrollment, and come to different conclusions.

One study, which treats students' high school achievement test scores as a control variable, finds no statistically significant total effects of desegregation in either the North or South on whether black students attend college, even though black students in mostly white high schools received lower high school grades and were less likely to be enrolled in a college preparatory curriculum. ${ }^{50}$ This study did find that school desegregation is related to the kind of college attended by blacks-Southern black college entrants were less likely to be found in one of the traditionally black colleges if more of their high school classmates were white. ${ }^{51}$ But further investigation of the data seems warranted under the assumptions of this study, to examine possible bias due to the significant fraction of the black sample that was omitted from these analyses because of missing test score data.

The second study using NLS data reported that the effects of high school desegregation on black students' college attendance were nonsignificantly negative in the South and positive in the North, after taking into account student differences in family socioeconomic background and characteristics of the high school district. ${ }^{52}$ This study differed from the first by not treating twelfth-grade achievement test scores as a control on self-selection into desegregated high schools, by studying effects on continuation to the junior year of college as well as on initial college enrollment, and by omitting about 25 percent of the black sample that was missing certain questionnaire variables other than test scores. ${ }^{53}$

It should be possible to improve on the deficiencies of both studies to get a clearer picture from the NLS data of the possible effects of elementary and secondary school desegregation on black students' college attendance. This will involve more careful definitions of college attendance and completion rates, including proper distinctions between two-year and four-year institutions, as well as specific treatment of possible bias arising from the omission of significant proportions of the sample because of missing data for some of the variables. $^{54}$

49. Crain \& Mahard, School Racial Composition and Black College Attendance and Achievement Test Performance, 51 Soc. of Educ. 81 (1978); Eckland, School Racial Composition and College Attendance Revisited, 52 Soc. of Educ. 22 (1979); Crain \& Mahard, Reply to Eckland, 52 Soc. of Educ., April 1979.

50. Eckland, supra note 49 , at 125

51. Id.

52. Crain \& Mahard, School Racial Composition and Black College Attendance and Achievement Test Performance, supra note 49.

53. Crain \& Mahard, Reply to Eckland, supra note 49, at 125-28.

54. Jomills H. Braddock is conducting these analyses at Johns Hopkins University. 


\section{Occupational Opportunities}

This section describes the present racial gaps in occupational opportunities and the degree of desegregation in places of work. This description goes beyond the more familiar studies of income and employment differences. Research showing that blacks continue to be channeled into a restricted range of less promising careers, and that most desegregation in places of work is found at the highest occupational levels where only a small proportion of blacks have gained access is reviewed. This is followed by a review of the limited evidence on the relationship between elementary and secondary desegregation and occupational opportunities.

\section{A. Occupational Attainments}

Although large racial differences remain in employment, family income, personal earnings, and occupational level, there was significant progress during the prosperous 1960s toward narrowing these black-white gaps, and this progress has not been negated by the general problems in the economy in the $1970 s^{55}$ Since 1960 , nonwhites have shifted into higher status, nonmanual, supervisory, and craft jobs at a faster rate than whites have, although a substantial occupational gap remains. Even after recent gains, the occupational status level for the average nonwhite worker in 1975 remained lower than what the average white worker had achieved in 1940 . Moreover, the relative improvement in occupational status has been greater for nonwhite females than for nonwhite males. The trends in family income also showed a more rapid rate of improvement during the $1960 \mathrm{~s}$ for blacks than for whites, although the black median family income in 1970 was 61 percent of the white median. This improvement in relative standing has not continued in the first half of the 1970s, although the earlier gains have been maintained. Unemployment remains an overriding problem for nonwhite Americans, and is one area where much of the narrowing of black-white differences that occurred during the 1960s has been lost during the 1970s, especially for males.

Although there has been much research on racial differences in occupational level-both occupational prestige or status and income levels-blackwhite differences in type of occupation have been examined only recently. Occupations have been classified according to the kinds of activities involved and the kinds of competencies that are required and rewarded. For example, some occupations require working with data; others, with people; and still others, with machines. Studies have shown that separate labor markets oper-

55. See, e.g., Farley, Trends in Racial Inequalities: Have the Gains of the 1960s Disappeared in the 1970s?, 42 Aм. Soc. Rev. 189 (1977). 
ate for broad groups of occupational types: most workers' careers involve job changes among similar or closely related occupational types, and the payoffs in income and job prestige for additional years of education vary significantly among these different types. ${ }^{56}$

Black workers are much more concentrated than whites in "social" occupations, such as education and social service jobs. Among the most highly educated workers in 1970, 47 percent of black men were in social occupations compared to 19 percent of white men of similar age and education. Further, black workers are greatly underrepresented in enterprising occupations such as business management or sales, and in investigative occupations such as scientific work. Among highly educated workers in 1970, 12 percent of black men compared to 39 percent of white men were in enterprising occupations, and 12 percent of black men compared to 21 percent of white men were in investigative work. ${ }^{57}$

These three broad types of occupations, which show the largest differences in racial distributions for occupational types, also appear to involve different market processes of occupational attainment. Studies of the returns received from additional years of schooling show that social occupations yield relatively large payoffs in occupational prestige but small returns in added income; enterprising jobs provide much higher income payoffs but lower prestige returns; and investigative work offers high returns in both income and prestige. Each additional year of education is associated with an additional annual increment to income of $\$ 200$ to $\$ 300$ in social occupations, $\$ 400$ to $\$ 600$ in investigative work, and about $\$ 1,000$ in enterprising work. ${ }^{58}$ Moreover, high incomes in enterprising jobs are often possible without attaining high levels of education, but high incomes in social occupations usually require advanced educational credentials. ${ }^{59}$ Thus, black males are greatly overrepresented in occupational types with the smallest income returns on education, and greatly underrepresented in occupational types with the largest income returns. ${ }^{60}$ This means that the opportunities for blacks to achieve high incomes will be restricted until the processes that channel them into a restricted range of career and occupational types are changed.

Further research is needed on the sources of the differences between blacks and whites in type of occupational choice, and on the possible effects of attending desegregated schools on occupational choices. Such research could indicate whether the occupational choices of blacks are affected by differences

56. L. Gottfredson, A Multiple-Labor Market Model of Occupational Achievement 22 (Johns Hopkins Center for the Social Organization of Schools Report 225, 1977) (ERIC Document No. $142809)$.

57. Gottfredson, Providing Black Youth More Access to Enterprising Work, 27 Vocational GuidANCE Q., December 1978, at 119 .

58. L. Gottfredson, supra note 56, at 18-19.

59. L. Gottfredson, supra note 56 , at 15.

60. Gottfredson, supra note 57, at 119-120. 
between segregated and desegregated schools in peer group occupational aspirations or in the networks of information that are available to connect students to nontraditional major fields in college or to nontraditional occupational opportunities.

\section{B. Desegregation of Places of Work}

Data on the number of workers from different racial and ethnic groups are collected annually by the federal Equal Employment Opportunities Commission (EEOC) for approximately 150,000 places of private employment in this country with 100 or more employees. ${ }^{61}$ Using the employment data collected by EEOC for $1975,{ }^{62}$ segregation indices and distributions by racial composition for places of work by job category have been calculated. Because the EEOC data used in these analyses did not include the regional location of each firm, only estimates for the nation as a whole could be calculated.

Indices of segregation for all jobs surveyed by the EEOC in 1975 and for nine different occupational levels are given in Table $4 .{ }^{63}$ The racial distribu-

61. U.S. Equal Employment Opportunity Comm'n, Minorities and Women in Private InDuSTRY 2 (Equal Employment Opportunity Comm'n Research Report No. 54, 1977). Responses to the EEOC survey covered $48 \%$ of the private nonagricultural work force, with more complete coverage in those industries whose establishments tend to be large. For example, it is estimated that the survey incudes $80 \%$ of the work force in durable goods manufacturing and $71 \%$ in nondurable manufacturing but only $31 \%$ of the retail work force and $29 \%$ of the wholesale trade work force. The racial composition of the 1975 EEOC sample is similar to the U.S. Bureau of Labor Statistics' 1975 estimate of the racial composition of the population with work experience, as reported by H. J. Becker, Racial Segregation Among Places of Employment 27 n.2 (paper presented at the annual meeting of the American Sociological Ass'n, at San Francisco, California, September 4-8, 1978).

62. Analyses are based on a random 1 in 20 sample of the 1975 EEOC survey $(N=7,483)$.

63. The method of calculating segregation indices is the same as that described in notes $18-20$ supra and accompanying text, where it was used to analyze higher education data.

The segregation index consists of two components. The first component is the "percent white in the same work place and occupational level in which the average black worker" is situated. The second component is the expected racial composition if the available white and black workers were randomly distributed among the job categories or the percentage of all workers who are white in the particular job category. These two components are used in the segregation index to measure the extent to which the actual percentage of white workers in the place of work and occupational level in which the average black worker is situated departs from the percentage expected if the workers were randomly distributed.

The index will have a value of 100 whenever white and black workers are totally segregated in their place of work; it will have a value of zero whenever the actual racial composition of the job category is the same as a random allocation of the workers would produce.

The segregation index formula for employment data is:

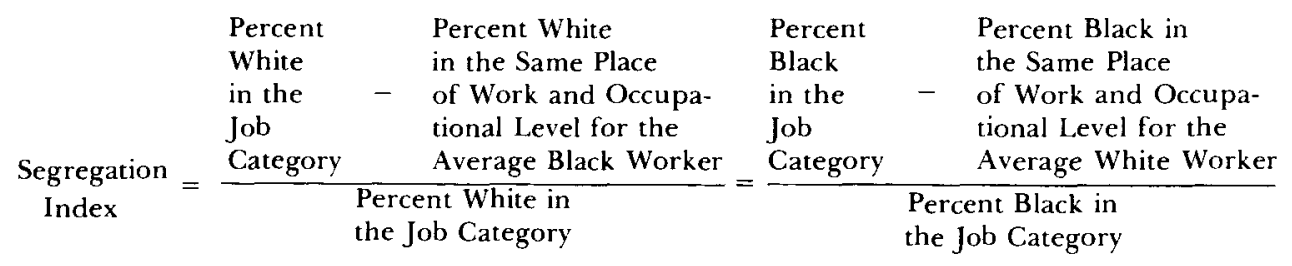


tion of workers in places of work for the same nine occupational levels is given in Table 5, providing an additional picture of the extent of segregation.

TABLE 4

1976 Nationwide Segregation Indichs for Places of Work, by Job Category

\begin{tabular}{cc}
$\begin{array}{c}\text { Job } \\
\text { Category }\end{array}$ & $\begin{array}{c}\text { tional Level } \\
\text { for the Average } \\
\text { Black Worker }\end{array}$ \\
\hline
\end{tabular}

All Jobs

Officials \& Managers

Professionals

Technical

Sales Workers

Office \& Clerical

Craft

Operative

Laborers

Service Workers

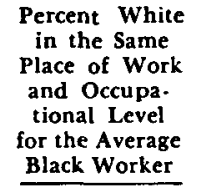

67.8

81.6

78.9

70.7

72.0

68.9

74.8

60.9

41.5

42.5

\begin{tabular}{|c|c|}
\hline & $\begin{array}{l}\text { Percent Black } \\
\text { in the Same }\end{array}$ \\
\hline $\begin{array}{l}\text { Percent } \\
\text { White } \\
\text { in the } \\
\text { Job } \\
\text { Category }\end{array}$ & $\begin{array}{l}\text { Place of Work } \\
\text { and Occupa- } \\
\text { tional Level } \\
\text { for the Average } \\
\text { White Worker }\end{array}$ \\
\hline
\end{tabular}

83.7

94.2

92.1

88.3

91.0

85.6

88.9

79.1

69.3

68.5
8.7

2.7

2.5

5.2

4.4

7.8

6.0

11.0

12.6

14.0

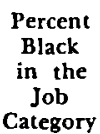

10.7

3.1

3.0

6.5

5.6

9.7

7.1

14.3

21.0

22.5
Segregation Index 19 15

14

20

21

20

16

23

40

38

Source: Data file tapes from Equal Employment Opportunities Commission 1975 Survey of Private Employers, 1/20 sample.

The analyses presented in Tables 4 and 5 indicate that there is less segregation in employment than in education, but some job categories are more highly segregated than others. The nationwide segregation index for all jobs is 19.0, compared to the nationwide segregation indices of 31.7 for higher education and $\mathbf{5 5 . 8}$ for elementary and secondary schools. ${ }^{64}$ This difference is also shown by comparison of the racial distribution in employment and education: only 13.9 percent of black workers are in places of work where more than half the employees are black, compared to the 35.4 percent minority students who attend undergraduate schools where more than half the students enrolled are minority, ${ }^{65}$ and the 60.4 percent minority students who attend elementary and secondary schools where more than half the students enrolled are minority. ${ }^{66}$

However, segregation among places of work is considerably greater for

Each value of the segregation index presented in Table 4 is an average of the index calculated from the perspective of the average white worker and of the average black worker, using components that include more decimal places than are shown in columns $1-4$. These reported values may differ somewhat from values calculated from the single decimal place components shown in the table.

64. Supra note 23; H. J. Becker, Racial Segregation Among Places of Employment, supra note 61 , at 10 \& Table 2.

65. See Table 2.

66. See text at note 23 , supra. 


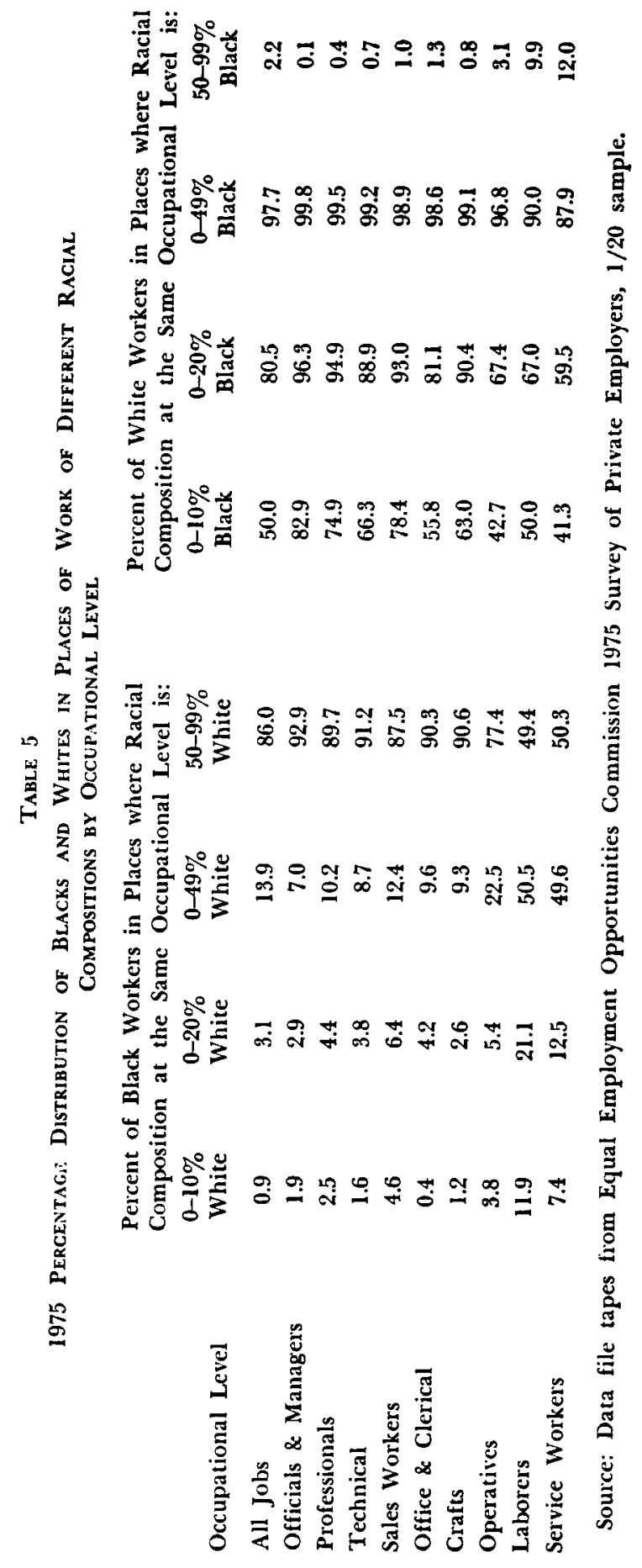


laborers and service workers than in other job categories. The segregation indices for laborers and service workers are about twice as large as the index for all jobs in the nation. ${ }^{67}$ And about half of the black workers who are employed as laborers and service workers are in places of work where more than half of those employed are black. By contrast, in most other job categories less than 15 percent of the black workers are employed in places where minority workers make up more than half of the work force.

The highest job categories of managerial, professional, technical, and sales workers are the least segregated. However, blacks are much more underrepresented at these levels than at other levels nationwide. The segregation indices for the top four job categories, as shown in column 5 of Table 4, range from 14 to 21 . At the same time, as shown in column 4 of Table 4 , only about 3 percent of all managers and professionals in the work force are black and about 6 percent of the nation's technical and sales workers are black, compared to a black representation of 10.7 percent in all jobs of the nation. This means that while blacks at the top levels are least likely to be concentrated in highly segregated places of work, only a small proportion of blacks have gained access to these levels in most firms. There are many more firms that have few or no blacks in these job categories compared to other job levels. Among whites, as shown in Table 5, more than two-thirds of the workers in each of the top four job categories are employed in places where less than 10 percent of their fellow workers are black. Indeed, about half the nation's white managers have no black co-workers at all, and about one-third to twofifths of the whites at the other top levels are in exclusively white work forces. ${ }^{68}$ In other job categories, only about one-quarter of whites find no blacks in the same job level at their place of work. ${ }^{69}$

These preliminary analyses suggest that different policies need to be implemented at higher and lower occupational levels to increase significantly the number of both white and black job holders who work in racially mixed work forces. The problem at the higher occupational levels is mainly the low proportional representation of blacks in these jobs. The problem at the lower occupational levels is the concentration of blacks and whites in work forces where their own race is in the majority. Further research is needed on the differences in the extent of segregation in employment within specific state, metropolitan, and industrial labor markets, on the effects of segregation in employment on male versus female workers, and on the relationship between segregation in employment and specific conditions of the firm and employer policies. ${ }^{70}$

67. See Table 4 .

68. H. J. Becker, Racial Segregation Among Places of Employment, supra note 61, at 10 \& Table 2.

69. Id.

70. Henry J. Becker is performing these analyses at Johns Hopkins University. 


\section{Elementary and Secondary School Desegregation and Occupational Outcomes}

The only analyses of the relationship between occupational outcomes and school desegregation have been based on data collected in the 1966 retrospective survey of black and white adults sponsored by the United States Commission on Civil Rights. ${ }^{71}$ The elementary and secondary school experiences reported in this survey extended from the 1930s to the early 1960s. Research has been undertaken on two classes of outcomes: income and occupational attainments of blacks; and attitudes toward race and related behaviors of blacks and whites that appear to have relevance for occupational outcomes.

One study analyzed approximately 300 cases from the original sample of 1,624 black adults aged twenty-one to forty-five in 1966 who had attended Northern high schools and who reported their employment. ${ }^{72}$ Black men from desegregated schools are more likely to hold nontraditional jobs in sales, crafts, and the professions (33 percent) than those who attended segregated schools (21 percent), and to have higher average occupational prestige and income (35.7 in prestige, $\$ 5,454$ in income) than those who attended segregated schools (34.0 in prestige, $\$ 5,110$ in income). When age, educational attainment, stability of family and origin are controlled, the estimated annual income advantage for blacks who attended desegregated schools is $\$ 100$.

Other studies based on these data have analyzed some attitudinal variables thought to be associated with black occupational success and have explored the degree to which segregated school experiences are perpetuated in adult life. It was found that both blacks and whites who attended desegregated schools are more likely to function in desegregated environments in later life. As adults, they were more frequently found to live in desegregated neighborhoods, to have children who attended desegregated schools, and to have close friends of the other race than did adults of both races who attended segregated schools. ${ }^{73}$ There is also some evidence that blacks from desegregated situations have a stronger sense that occupational opportunities are available to them, more confidence in their ability to succeed in interracial situations, and more access to informal sources of information about employment opportunities, all of which may be important for adult occupational success. ${ }^{74}$

To gain a better understanding of the extent to which segregation in education is perpetuated in adult life and of the occupational effects of school desegregation, research is needed on larger and more contemporary samples. Some useful studies can be made with existing longitudinal data, such as those

71. Note 31. supra, and accompanying text.

72. Crain, supra note 32 , at 595 .

73. U.S. Comm N on Civil. Rights, supra note 31.

74. R. Crain \& C. Weisman, Discrimination, Personality and Achievement: A Survey of NorTHERN Blacks, ch. 10 (1972). 
obtained through the National Longitudinal Study of the High School Class of 1972, but new data will be needed to examine most of these questions directly.

\section{Conclusion}

There is always the danger of drawing misleading implications from any evaluation research. Better data and research designs may yield different results, or may reveal significant side effects or unanticipated consequences from as yet unmeasured outcomes. For the topics addressed in this article, where the information needed is inadequate for describing many important aspects of black-white differences in attainments in higher education and employment, for linking elementary and secondary school desegregation to adult outcomes, and for understanding the processes that relate improvements in equity or desegregation across institutions and across generations, the dangers of misinterpretation are great.

As this article has indicated, assessments based on limited data may lead to incorrect conclusions. Entry level enrollment rates in higher education may give a superficial impression of equity of attainment that overlooks important black-white differences in continuation or completion rates and in the type or quality of the college attended. Similarly, income and prestige differences in the occupational structure may be better understood by examining the distribution of black and white workers among different types of work and labor markets. The usefulness of further descriptive research on the extent of segregation in higher education and employment is evident. Conclusions based on analysis of data for regional and national categories may alter when particular state and community conditions are taken into account.

The existing data bases do not appear nearly so promising for evidence about the effects of elementary and secondary school desegregation on posthigh school educational and occupational choices and attainments. With few exceptions, current evidence is based on data that are derived either from very small samples or unrepresentative samples, or from data that are out of date. As a consequence, little can be said with much confidence about most of these questions. Although further analysis of the data from the National Longitudinal Survey of the High School Class of 1972-especially data on the college completion years-should provide valuable evidence on some of the questions raised in this article, major new data collections will probably be needed to make real progress in understanding the effects of school desegregation on higher education and employment opportunities. 